\title{
Biological Control of Annual Bluegrass with Xanthomonas campestris pv. poannua in Bermudagrass
}

\author{
B. Jack Johnson' \\ Department of Crop and Soil Sciences, University of Georgia, Georgia \\ Station, Griffin, GA 30223-1797
}

Additional index words. Poa annua, Lolium perenne, Cynodon transvaalensis $\times$ C. dactylon

\begin{abstract}
Xanthomonas campestris pv. poannua has potential as a biological control agent for perennial ryegrass (Lolium perenne $\mathbf{L}$.), and it is being evaluated as a commercial bioherbicide. Field experiments were conducted on dormant 'Tifway' bermudagrass [Cynodon transvaalensis Burtt-Davy $\times$ C. dactylon (L.) Pers.] and 'Tifway' bermudagrass overseeded with perennial ryegrass to determine the effects of two isolates of $X$. campestris pv. poannua on annual bluegrass (Poa annua L.) control. Annual bluegrass control was $82 \%$ on 27 Apr. 1992 after isolate MB 218 was applied to dormant bermudagrass at $10^{\circ} \mathrm{cfu} /$ $\mathrm{ml}$ in three applications on 11 and $28 \mathrm{Feb}$. and 12 Mar. When isolate MB 245 was applied at the same rate and dates, it controlled only $60 \%$ of the annual bluegrass. The response from isolate MB 245 at the same rate and number of applications on 28 Apr. 1993 was similar to that in Apr. 1992, with $64 \%$ control on dormant turf and $52 \%$ control on overseeded turf. There was no significant advantage in annual bluegrass control when isolate MB 245 was applied at $10^{\circ} \mathrm{cfu} / \mathrm{ml}$ in more than three applications during the fall and winter, compared to three applications on $15 \mathrm{Feb}$. and 1 and $11 \mathrm{Mar}$. when ratings were made on 28 Apr. 1993. The control of annual bluegrass in late Apr. 1992 and 1993 from X. campestris applied in three applications (11 and $28 \mathrm{Feb}$. and $12 \mathrm{Mar} .1992$ and $15 \mathrm{Feb}$. and 1 and 11 Mar. 1993) at $10^{9} \mathrm{cfu} / \mathrm{ml}$ was greater than when $10^{8} \mathrm{cfu} / \mathrm{ml}$ was applied on the same dates.
\end{abstract}

Annual bluegrass is a common winter annual in turfgrasses throughout the United States, particularly in the southeast where bermudagrass golf greens are overseeded in the fall with cool-season grasses. Preemergence (Bingham and Shaver, 1979; Johnson, 1984) and postemergence (Johnson, 1984) herbicides have controlled annual bluegrass effectively in nonoverseeded bermudagrass. However, the selection of herbicides applied for annual bluegrass control in overseeded bermudagrass is limited because preemergence herbicides, with the exception of $\alpha$-(2chlorophenyl) - $\alpha$-ct-(4-chlorophenyl) -5pyrimidinemethanol (fenarimol), must be applied 60-90 days before overseeding to obtain good germination of the overseeded cool-season grasses (Bingham et al., 1969; Mazur, 1976). In contrast, herbicides applied at this time generally do not control annual bluegrass consistently (Johnson, 1975). Herbicides applied after overseeding often cause injury to the overseeded cool-season turf (Dickens, 1979; Johnson, 1983, 1988a). Fenarimol can be applied closer to overseeding (Grant et al.,

\footnotetext{
Received for publication 11 June 1993. Accepted for publication 13 Nov. 1993. Supported by state and Hatch Act funds allocated to the Georgia Agricultural Expt. Stations and by Grant-in-aid from MycogenCorp.I thank W. Olson, M. Gilmer, andT. Dinkins for technical assistance. The cost of publishing this paper was defrayed in part by the paymentofpagecharges.Under postal regulations, this paper therefore must be hereby marked advertisement solely to indicate this fact.

${ }^{\text {'Professor. }}$
}

chambers, this pathovar-controlled annual bluegrass $274 \%$ in North Carolina and $90 \%$ in New York. However, annual bluegrass control in a field study was $\leq 38 \%$ in New York (Neal et al., 1992). The weed species in North Carolina was annual bluegrass [Poa annua (L.) var. Timm.], but the researchers used a perennial biotype of Poa annua [Pea annua (L.) var. reptans] in New York. Xanthomonas campestris pv. poannua had activity on the annual biotype Poa annua (Kalmowitz et al., 1992) but not on field-grown, perennial biotype reptans (Neal et al., 1992). Crowley ( 1992) reported that annual bluegrass control in five states averaged $\leq 74 \%$ with $X$. campestris pv. poannua applied at $10^{8}$ and $10^{9} \mathrm{cftu} / \mathrm{ml} 28-77$ days after treatment.

Because Poa annua var. annua is a problem weed in most turfgrasses throughout the southern United States and X. campestris pv. poannua has biological activity on this weed, experiments were initiated to determine the application timing and frequency that this bacterium needed for annual bluegrass control in Georgia-. Also, I studied the tolerance of perennial ryegrass and bermudagrass to the pathovar. The $X$. campestris isolates evaluated in New York and North Carolina are the same that were evaluated in Georgia (personal communication from Keith Jones, Mycogen Corp., Griffin). Isolate MB 245 is deposited in the Northern Regional Research Center Culture Collection with isolate number B-18855.

\section{Materials and Methods}

1986), but it does not control annual bluegrass consistently (Gaul and Christians, 1988; Johnson, 1988b).

Herbicides are most commonly used to control annual bluegrass and other weeds in ttrrfgrasses. However, various organizations have lobbied to restrict using herbicides because of environmental and human health concerns. Biological weed control agents may offer effective alternatives to herbicides. Researchers in Arkansas (Heiny et al., 1991; Weidemann et al., 1992) reported that the fungal pathogens Microsphaeropsis amaranthi [(E11. \& Banth.) Heiny \& Mintz] controlled certain pigweed (Amaranthus) species, Phoma proboscis Heiny controlled field bindweed (Convolvulus arvensis L.), and Colletotrichum capsici Syd. controlled pitted and sharppod morningglory (Ipomoea spp. ). In Canada (Riddle et al., 1991), isolates of Sclerotinia sclerotiorum (Lib.) de Bary and S. minor Jagger reduced the population of dandelions (Taraxacum ojficinale Weber in Wiggers). In Georgia (Phatak et al., 1983), rust epiphytotics of Puccinia canaliculata (Schw.) Lagerh. established in early spring reduced stand and tuber formation and completely inhibited flowering of yellow nutsedge (Cyperus esculentus L.).

Roberts et al. (1981) and Roberts and Vargas (1984) isolated $X$. campestris, anew disease in Toronto creeping bentgrass (Agrostis palustris Huds.) that causes bacterial wilt. Researchers in New York (Neal et al., 1992) and North Carolina (Kalmowitz et al., 1992) have indicated that $X$. campestris pv. poannua has pathogenic activity on annual bluegrass. In growth
Three experiments were conducted on turfgrasses for annual bluegrass (Pea annua var. апnиа) control with bacterium $X$. campestris pv. poannua in Griffin, Ga., during 1992 and 1993. In the first experiment, treatments were applied to a dormant 'Tifway' bermudagrass putting green during Winter and early Spring 1992. Treatments in the second and third experiments were applied to 'Tifway' bermudagrass not overseeded and to 'Tifway' bermudagrass overseeded with perennial ryegrass during the Fall and early Winter 1992 and late Winter and early Spring 1993.

The experimental areas were overseeded with annual bluegrass before treatment each year. The site in 1992 was overseeded at 245 $\mathrm{kg} \cdot \mathrm{ha}^{-1}$ on 7 Oct. 1991; in 1993, the site was overseeded at $146 \mathrm{~kg} \cdot \mathrm{ha}^{-1}$ on $12 \mathrm{Aug} .1992$. Perennial ryegrass was seeded into the bermudagrass putting green at $1700 \mathrm{~kg} \cdot \mathrm{ha}^{-1}$ on 2 Oct. 1992. About 6 weeks before overseeding with annual bluegrass, the bermudagrass turf was cored and vertically mowed to remove excess thatch. Before seeding perennial ryegrass, the turf was lightly vertically mowed, grooving the turf to aid ryegrass germination. Immediately after seeding annual bluegrass and perennial ryegrass, the turf area was covered with $3.5 \mathrm{~mm}$ of sand.

Bermudagrass overseeded only with annual bluegrass was mowed to a height of $8 \mathrm{~mm}$ until dormancy in late October or early November. Bermudagrass overseeded with annual bluegrass in mid-August was mowed to a height of $8 \mathrm{~mm}$ until early October when 
perennial ryegrass was seeded. After perennial ryegrass seeding, the turfgrass was mowed at a height of $10 \mathrm{~mm}$ for 3 weeks; then the cutting height was reduced to $8 \mathrm{~mm}$ until February. The grass was mowed and clippings were removed three times per week during spring, summer, and fall, and twice per week during the winter.

Turfgrass overseeded with annual bluegrass and perennial ryegrass was fertilized with $50 \mathrm{~N}-22 \mathrm{P} 42 \mathrm{~K}\left(\mathrm{~kg} \cdot \mathrm{ha}^{-1}\right)$ in October. An additional $50 \mathrm{~kg} \mathrm{~N} / \mathrm{ha}$ was applied at about monthly intervals. In April and June, an additional $22 \mathrm{~kg} \mathrm{P} / \mathrm{ha}$ and $42 \mathrm{~kg} \mathrm{~K} / \mathrm{ha}$ were applied. The fertilizer schedule was the same both years. Rainfall was supplemented with irrigation as needed.

Mycogen Corp. (San Diego, Calif.) provided the isolates of MB 218 and MB 245 of $X$. campestris pv. poannua used in these studies and determined the $\mathrm{cfu} / \mathrm{ml}$ rate. A new lot of bacteria was shipped overnight, packed in ice, before each treatment. When received, it was refrigerated; the inoculum was potent for $\leq 7$ days. Inmost instances, treatments were made within 2 to 3 days after the inoculum was shipped.

In the first experiment, isolates of MB 218 and MB 245 were applied to separate plots at $10^{8}$ and $10^{\circ} \mathrm{cfu} / \mathrm{ml}$ in three applications during 1992. Each inoculum rate was initially applied on 22 Jan. 1992 and followed by 3 and 11 Feb. applications. Alternatively, the inoculum was applied initially on 11 Feb. 1992 and followed by $28 \mathrm{Feb}$. and 12 Mar. applications on a dormant turf overseeded with annual bluegrass. The second (dormant bermudagrass overseeded with annual bluegrass) and third (bermudagrass overseeded with perennial ryegrass and annual bluegrass) experiments were conducted with isolate MB 245 applied at $10^{8}$ and $10^{9} \mathrm{cfu} / \mathrm{ml}$ rates during 1992 and 1993. Frequency and number of MB 245 applications were as follows (cfu/ml): 1) $10^{9}$ applied in each of seven applications on 14 Sept., 12 Oct., 17 Nov., and 14 Dec. 1992 and 14 Jan., 15 Feb., and 11 Mar. 1993; 2) $10^{\circ}$ applied in each of four applications on 14 Sept., 17 Nov., and 14 Dec. 1992 and 28 Jan. 1993 ; 3) $10^{9}$ applied in each of four applications on 14 and 28 Jan., 15 Feb., and 1 Mar. 1993; 4) 108 and $10^{9}$ applied in each of three applications to separate plots on 14 and 28 Jan. and 15 Feb. 1993; and 5) $10^{8}$ and $10^{9}$ applied in each of three applications to separate plots on 15 Feb. and 1 and 11 Mar. 1993. Fenarimol applied at $2.3 \mathrm{~kg} \cdot \mathrm{ha}^{-1}$ on 2 and 14 Sept. 1992 and $0.8 \mathrm{~kg} \cdot \mathrm{ha}^{-1}$ on $14 \mathrm{Jan} .1993$ was included as a herbicide control in the second and third experiments. A nontreated control was included in all experiments.

All $X$. campestris treatments were applied as broadcast sprays using compressed air with a Solo backpack sprayer (Ben Meadows Co., Atlanta) in 938 liters water/ha. The inoculum spray was applied at $152 \mathrm{kPa}$. Fenarimol was broadcast-applied with a $\mathrm{CO}_{2}$ sprayer in 375 liters water/ha. Fenarimol was applied at 172 $\mathrm{kPa}$. All X. campestris and fenarimol treatments were applied to turfgrass maintained at an 8 -mm height. The inoculated plants were cut with a walking reel mower to a height of $5.6 \mathrm{~mm}$ immediately after spraying because the inoculum needs fresh wounds to enter the plants (Keith Jones, Mycogen Corp., personal communication). The mower reels were thoroughly rinsed with water after each isolate application to prevent contamination.

One day after the final $X$. campestris treatments were made (12 Mar. 1992 and 11 Mar 1993), the grass in the test area was mowed uniformly to a height of $5.6 \mathrm{~mm}$. The turfgrass and annual bluegrass were allowed to grow until final ratings were made 27 Apr. 1992 and 28 Apr. 1993. This allowed seedheads to emerge from the annual bluegrass, thus making comparisons to nontreated controls more reliable.

Annual bluegrass control and turf quality were visually rated at weekly intervals for $\approx 7$ weeks after the final Xanthomonas campestris treatment. Weed control ratings were based on seedheads in nontreated plots where $0=$ no control and $100=$ complete, uniform, dense stand. Xanthomonas campestris treatments were arranged in a randomized complete-block design with four replications. Plot size was 2.4 $\times 3.0 \mathrm{~m}$. I performed an analysis of variance using the general linear model procedure (SAS Institute, 1982) for each experiment and compared differences using Duncan's multiple range test at $P \leq 0.05$.

\section{Results and Discussion}

Dormant bermudagrass, 1992. Xanthomonas campestris isolate MB 218 applied at $10^{9} \mathrm{cfu} /$ $\mathrm{ml}$ in three applications on 11 and $28 \mathrm{Feb}$. and 12 Mar. 1992 achieved control of $91 \%$ annual bluegrass in dormant bermudagrass turf when ratings were made 1 Apr. (Table 1). The control was reduced to $82 \%$ by 27 Apr. When the same isolate was applied in three applications at $10^{\circ} \mathrm{cfu} / \mathrm{ml}$ on $22 \mathrm{Jan}$. and 3 and 11 Feb., the control on 15 and 27 Apr. was not as effective $(66 \%$ to51\%) as when applied at the same rate on 11 and $28 \mathrm{Feb}$. and $12 \mathrm{Mar}$. (82\% to $83 \%$ ). Crowley ( 1992) suggested that warm weather following treatments results in quicker annual bluegrass control. In my study, the mean highlow air temperature 21 days following the last

Table 1. Influence of Xanthomonas campestris pv. poannua treatments on annual bluegrass control and bermudagrass quality in dormant bermudagrass green, 1992.

\begin{tabular}{|c|c|c|c|c|c|c|c|}
\hline \multirow[b]{2}{*}{ Herbicide } & \multirow{2}{*}{$\begin{array}{c}\text { Time of } \\
\text { application }\end{array}$} & \multirow{2}{*}{$\begin{array}{c}\begin{array}{c}\text { Rate } \\
\text { (cfu/ml) }\end{array} \\
\end{array}$} & \multicolumn{3}{|c|}{ Annual bluegrass control $(\%)^{z, y}$} & \multicolumn{2}{|c|}{$\begin{array}{c}\text { Bermudagrass } \\
\text { quality }^{\mathrm{z}, \mathrm{x}}\end{array}$} \\
\hline & & & $1 \mathrm{Apr}$. & 15 Apr. & 27 Apr. & $21 \mathrm{Apr}$. & $27 \mathrm{Apr}$. \\
\hline None & & -- & $\frac{1}{0 \mathrm{~d}}$ & $0 \mathrm{e}$ & $0 \mathrm{e}$ & $1.6 \mathrm{~d}$ & $1.5 \mathrm{e}^{-}$ \\
\hline \multirow[t]{4}{*}{ MB 218} & Early & $10^{8}$ & $46 \mathrm{~b}$ & $47 \mathrm{c}$ & $39 \mathrm{~cd}$ & $6.1 \mathrm{~b}$ & $5.1 \mathrm{bcd}$ \\
\hline & Earlyw & $10^{9}$ & $87 a$ & $66 \mathrm{ab}$ & $51 \mathrm{bc}$ & $7.1 \mathrm{ab}$ & $6.3 \mathrm{abc}$ \\
\hline & Late $^{v}$ & $10^{8}$ & $53 \mathrm{~b}$ & $51 \mathrm{bc}$ & $39 \mathrm{~cd}$ & $6.4 \mathrm{~b}$ & $4.1 \mathrm{~cd}$ \\
\hline & Late $^{v}$ & $10^{9}$ & 91 a & $83 a$ & $82 \mathrm{a}$ & $8.8 \mathrm{a}$ & $8.6 \mathrm{a}$ \\
\hline \multirow[t]{4}{*}{ MB 245} & Earlyw & $10^{8}$ & $31 \mathrm{bc}$ & $28 \mathrm{~d}$ & $28 \mathrm{~d}$ & $4.5 \mathrm{bc}$ & $4.1 \mathrm{~cd}$ \\
\hline & Early ${ }^{w}$ & $10^{9}$ & $52 \mathrm{~b}$ & $47 \mathrm{c}$ & $42 \mathrm{~cd}$ & $6.3 \mathrm{~b}$ & $5.5 \mathrm{bcd}$ \\
\hline & Late $^{v}$ & $10^{8}$ & $13 \mathrm{~cd}$ & $12 \mathrm{de}$ & $13 \mathrm{e}$ & $3.5 \mathrm{~cd}$ & $3.2 \mathrm{de}$ \\
\hline & Late $^{v}$ & $10^{9}$ & $39 \mathrm{~b}$ & $53 \mathrm{bc}$ & $60 \mathrm{~b}$ & $6.5 \mathrm{~b}$ & $7.1 \mathrm{ab}$ \\
\hline
\end{tabular}

${ }^{2}$ Values with a common letter within columns are not significantly different as tested by Duncan's multiple range test at $P \leq 0.05$.

y Annual bluegrass control ratings ranged from $0=$ no control to $100=$ complete control.

Turf quality ratings ranged from $1=$ turf brown to $10=$ dark green with complete uniform cover.

"Treatments were applied on 22 Jan. and 3 and 11 Feb. 1992.

vTreatments were applied on 11 and 28 Feb. and 12 Mar. 1992. 
through mid-March for a total of seven applications. The lower control from fall and early winter treatments was probably related to annual bluegrass that had not germinated or not grown enough for the reel mower to cut the leaves at treatment (this $X$. campestris pathovar needed fresh wounds to enter the annual bluegrass plants).

Annual bluegrass control on 28 Apr. did not increase when $X$. campestris isolate MB 245 was applied at $10^{9} \mathrm{cfu} / \mathrm{ml}$ in four applications on 14 and 28 Jan., 15 Feb., and 1 Mar. $(56 \%)$, compared with three applications at the same rate on $15 \mathrm{Feb}$. and 1 and 11 Mar. (64\%) (Table 2). The lack of difference between three and four applications is unexplained. The mean high-low temperature was the same $(6.4 \mathrm{C})$ for each 2-week period following the three or four applications. However, the control level was consistently lower when $X$. campestris isolate MB 245 was applied in three applications at

$108 \mathrm{cfu} / \mathrm{ml}$ rather than in three applications at $109 \mathrm{cfu} / \mathrm{ml}$, regardless of whether treatments were initiated mid-January or mid-February.

Annual bluegrass control with fenarimol in dormant bermudagrass turf was unacceptable $(\leq 42 \%)$ (Table 2$)$. The control from fenarimol and MB 245 inoculum applied at $10^{9} \mathrm{cfu} / \mathrm{ml}$ on $15 \mathrm{Feb}$. and 1 and 11 Mar. was similar when ratings were made 6 Apr. However, by 19 Apr., control was significantly better in the $X$. campestris- treated plots than in fenarimol-treated plots. When final ratings were made 28 Apr., they showed that $X$. campestris pv. poannua applied at $10^{9} \mathrm{cfu} / \mathrm{ml}$ in three applications on 15 Feb. and 1 and 11 Mar. controlled $64 \%$ annual bluegrass. There was no advantage in annual bluegrass control from more than three inoculum treatments, compared to treatments initiated mid-February and repeated at 2-week intervals for a total of three applications.

Table 2. Influence of Xanthomonas campestris pv. poannua treatments on annual bluegrass control in dormant bermudagrass green and bermudagrass greens overseeded with perennial ryegrass, 1993.

\begin{tabular}{|c|c|c|c|c|c|c|c|c|}
\hline \multirow[b]{3}{*}{ Herbicide } & \multirow{3}{*}{$\begin{array}{c}\text { No. } \\
\text { application }\end{array}$} & \multirow[b]{3}{*}{ Rate } & \multicolumn{6}{|c|}{ Annual bluegrass control $^{\mathrm{z}}(\%)$} \\
\hline & & & \multicolumn{3}{|c|}{ Dormant bermudagrass } & \multicolumn{3}{|c|}{ Overseeded bermudagrass } \\
\hline & & & 6 Apr. & 19 Apr. & $28 \mathrm{Apr}$. & 6 Apr. & 19 Apr. & 28 Apr. \\
\hline None & --- & --- & $0 \mathrm{a}$ & $0 \mathrm{~d}$ & $0 \mathrm{~d}$ & $0 \mathrm{c}$ & $0 \mathrm{e}$ & $0 \mathrm{e}$ \\
\hline \multirow[t]{2}{*}{ Fenarimol } & & $\begin{array}{c}2.3+2.3+ \\
0.8 \mathrm{~kg} \cdot \mathrm{ha}^{-1 \mathrm{y}}\end{array}$ & $42 \mathrm{a}$ & $24 \mathrm{bc}$ & $16 \mathrm{~cd}$ & $58 \mathrm{a}$ & $37 \mathrm{bc}$ & $37 \mathrm{bc}$ \\
\hline & & $(c f u / m l)$ & & & & & & \\
\hline \multirow[t]{7}{*}{ MB 245} & $7^{x}$ & $10^{9}$ & $44 \mathrm{a}$ & $53 \mathrm{a}$ & $53 \mathrm{a}$ & $65 \mathrm{a}$ & $62 \mathrm{a}$ & $62 \mathrm{a}$ \\
\hline & 4 (Early)w $^{w}$ & $10^{9}$ & $31 \mathrm{a}$ & $28 b c$ & $27 \mathrm{bc}$ & $51 \mathrm{a}$ & $35 \mathrm{bc}$ & $35 \mathrm{bcd}$ \\
\hline & 4 (Late) $^{\mathrm{v}}$ & $10^{9}$ & $54 \mathrm{a}$ & $53 \mathrm{a}$ & $56 \mathrm{a}$ & 55 a & $54 \mathrm{ab}$ & $53 \mathrm{ab}$ \\
\hline & 3 (Early) $^{u}$ & $10^{8}$ & $0 \mathrm{a}$ & 0 & $0 \mathrm{~d}$ & $29 \mathrm{~b}$ & $22 \mathrm{~cd}$ & $15 \mathrm{de}$ \\
\hline & $3\left(\right.$ Early $^{\mathrm{u}}$ & $10^{9}$ & $52 \mathrm{a}$ & $43 \mathrm{ab}$ & $47 \mathrm{ab}$ & $49 \mathrm{a}$ & $48 \mathrm{ab}$ & $41 \mathrm{ab}$ \\
\hline & $3(\text { Late })^{t}$ & $10^{8}$ & $0 \mathrm{a}$ & $17 \mathrm{~cd}$ & $22 \mathrm{~cd}$ & $9 \mathrm{c}$ & $12 \mathrm{de}$ & $17 \mathrm{cde}$ \\
\hline & 3 (Late) $^{t}$ & $10^{9}$ & 31 a & $57 \mathrm{a}$ & $64 \mathrm{a}$ & $29 \mathrm{~b}$ & $41 \mathrm{abc}$ & $52 \mathrm{ab}$ \\
\hline
\end{tabular}

${ }^{2}$ Annual bluegrass control ratings ranged from $0=$ no control to $100=$ complete control. Values with a common letter within columns are not significantly different as tested by Duncan's multiple test at $P \leq 0.05$. 'Treatments were applied 2 and 14 Sept. 1992 and 14 Jan. 1993, respectively.

xTreatments applied 14 Sept., 12 Oct., 17 Nov., and 14 Dec. 1992 and 14 Jan., 15 Feb., and 11 Mar. 1993. "Treatments applied 14 Sept., 17 Nov., and 14 Dec. 1992 and 28 Jan. 1993.

"Treatments applied 14 and 28 Jan., 15 Feb., and 1 Mar. 1993.

"Treatments applied 14 and 28 Jan. and 15 Feb. 1993.

Treatments applied 15 Feb. and 1 and 11 Mar. 1993.

Table 3. Influence of Xanthomonas campestris pv. poannua treatments on quality of bermudagrass overseeded or not overseeded with perennial ryegrass, 1993.

\begin{tabular}{|c|c|c|c|c|c|c|}
\hline \multirow[b]{3}{*}{ Herbicide } & \multirow{3}{*}{$\begin{array}{l}\text { No. } \\
\text { applications }\end{array}$} & \multirow[b]{3}{*}{ Rate } & \multicolumn{4}{|c|}{ Turf quality $^{z}$} \\
\hline & & & \multicolumn{2}{|c|}{ Overseeded } & \multicolumn{2}{|c|}{ Not overseeded } \\
\hline & & & 29 Mar. & $19 \mathrm{Apr}$. & 6 Apr. & $13 \mathrm{Apr}$ \\
\hline \multirow{3}{*}{$\begin{array}{l}\text { None } \\
\text { Fenarimol }\end{array}$} & $-\cdots$ & --- & $6.6 \mathrm{a}$ & $5.4 \mathrm{~b}$ & $6.6 \mathrm{a}$ & $5.4 \mathrm{a}$ \\
\hline & & $\begin{array}{c}2.3+2.3+ \\
0.4 \mathrm{~kg}^{2} \mathrm{ha}^{-1 \mathrm{l}}\end{array}$ & $6.3 \mathrm{ab}$ & $7.6 \mathrm{a}$ & $6.0 \mathrm{ab}$ & $6.3 \mathrm{a}$ \\
\hline & & $(c f u / m l)$ & & & & \\
\hline \multirow[t]{7}{*}{ MB 245} & $7^{x}$ & $10^{9}$ & $5.5 \mathrm{bc}$ & $7.3 \mathrm{ab}$ & $5.5 \mathrm{bc}$ & $6.2 \mathrm{a}$ \\
\hline & 4 (Early) & $10^{9}$ & $5.5 \mathrm{bc}$ & $7.0 \mathrm{ab}$ & $5.5 \mathrm{bc}$ & $5.9 \mathrm{a}$ \\
\hline & $4($ Late) & $10^{9}$ & $4.1 \mathrm{~d}$ & $6.6 \mathrm{ab}$ & $4.5 \mathrm{~cd}$ & $5.5 \mathrm{a}$ \\
\hline & 3 (Early) $^{u}$ & $10^{8}$ & $4.8 \mathrm{~cd}$ & $5.6 \mathrm{~b}$ & $4.3 \mathrm{~d}$ & $4.6 \mathrm{a}$ \\
\hline & 3 (Early) & $10^{9}$ & $5.0 \mathrm{~cd}$ & $6.1 \mathrm{~b}$ & $4.5 \mathrm{~cd}$ & $5.2 \mathrm{a}$ \\
\hline & $3{\text { (Late })^{t}}^{t}$ & $10^{8}$ & $5.1 \mathrm{~cd}$ & $6.2 \mathrm{ab}$ & $4.3 \mathrm{~d}$ & $5.6 \mathrm{a}$ \\
\hline & 3 (Late) $^{t}$ & $10^{9}$ & $5.5 \mathrm{ab}$ & $7.8 \mathrm{a}$ & $4.8 \mathrm{~cd}$ & $5.9 \mathrm{a}$ \\
\hline
\end{tabular}

$\overline{{ }^{2} \text { Turf quality ratings ranged from } 1=\text { turf brown to } 10=\text { dark green with complete uniform cover. Values }}$ with a common letter within columns are not significantly different as tested by Duncan's multiple test at $P \leq 0.05$.

'Treatments applied 2 and 14 Sept. 1992 and 14 Jan. 1993, respectively.

xTreatments applied 14 Sept., 12 Oct., 17 Nov., and 14 Dec. 1992 and 14 Jan., 15 Feb., and 11 Mar. 1993.

wTreatments applied 14 Sept., 17 Nov., and 14 Dec. 1992 and 28 Jan. 1993.

'Treatments applied 14 and 28 Jan., 15 Feb., and 1 Mar. 1993.

"Treatments applied 14 and $28 \mathrm{Jan}$. and 15 Feb. 1993.

'Treatments applied 15 Feb. and 1 and 11 Mar. 1993.
Overseeded bermudagrass, 1993. In most instances, annual bluegrass control with $X$. campestris isolate MB 245 was similar whether the bermudagrass was dormant or overseeded with perennial ryegrass (Table 2), although no direct statistical comparison was performed. I expected that $X$. campestris treatments applied to overseeded turf would control a higher percentage of annual bluegrass than when applied to dormant turf. However, perennial ryegrass did not have a dense stand, thus the competition from perennial ryegrass was eliminated.

These results show that $X$. campestris pv. poannua has postemergence activity on annual bluegrass in dormant and overseeded bermudagrass greens. However, the degree of control obtained in this study would not be acceptable by most golf course superintendents. The timing and rates of $X$. campestris treatments were important in obtaining maximum annual bluegrass control. There was generally no advantage from fall plus winter treatments when compared with treatments made mid-February and repeated at 2-week intervals for a total of three applications. In all instances, annual bluegrass control in late April was higher when isolate MB 245 was applied at $10^{9}$ than at $10^{8} \mathrm{cfu} / \mathrm{ml}$.

Annual bluegrass can be readily controlled with several preemergence and postemergence herbicides in dormant bermudagrass turf (Bingham and Shaver, 1979; Johnson, 1984). Therefore, the use of $X$. campestris pv. poannua normally would not be an advantage in nonoverseeded bermudagrass. Because annual bluegrass is more difficult to control in bermudagrass greens overseeded with perennial ryegrass (Dickens, 1979; Johnson, 1983), the use of the bacterium for control may be feasible. However, additional research is needed with $X$. campestris to improve annual bluegrass control.

Turfgrass quality. The quality of nonoverseeded bermudagrass in 1992 was inversely related to annual bluegrass population (Table 1). Therefore, turf quality was directly related to annual bluegrass control. However, the quality of overseeded and nonoverseeded turf was lower in selected $X$. campestris- treated plots not related to annual bluegrass population in 1993 (Table 3). The quality of nonoverseeded turf on 6 Apr. was lower in all X. campestristreated plots when compared with nontreated turf. By 13 Apr., there was no difference in quality of turf between treated or nontreated plots. The lower quality in nontreated plots at this date was related to increased annual bluegrass population.

The quality of overseeded bermudagrass turf was lower in $X$. campestris- treated plots when compared with nontreated turf on 29 Mar. (Table 3). The lower quality was temporary, and by 19 Apr., the quality in treated plots was equal to or higher than quality in nontreated plots. The lower quality ratings in nontreated plots were due to annual bluegrass. I do not know why turf quality in overseeded and nonoverseeded plots was lower for a short period in 1993 when treated with the isolates. 


\section{Literature Cited}

Bingham, S. W., R.E. Schmidt, and C.K. Curry. 1969. Annual bluegrass control in overseeded bermudagrass putting green turf. Agron. J. 61:908-911,

Bingham, S. W.and R.L. Shaver. 1979. Effectiveness of herbicide programs for annual bluegrass (Poa апnиа) control in bermudagrass (Cynodon dactylon). Weed Sci. 27:367-370.

Crowley, R.H. 1992. Control of annual bluegrass (Poa аппиа var. аппиа) in southern turf with the biological Xanthomonas campestris pv poannиа. Proc. Southern Weed Sci. Sot. 45:127.

Dickens, R. 1979. Control of annual bluegrass (Poa аппиа) in overseeded bermudagrass (Cynodon sp.) golf greens. Weed Sci. 27:642+44

Gaul, M.C. and N.E. Christians. 1988. Selective control of annual bluegrass in cool-season turfs with fenarimol and chlorsulfuron. Agron. J. 80:120-125.

Grant, D. L., R.B. Cooper, R.D. Hicks, C.E. Moore, and H.L Webster. 1986, Fenarimol (EL-222) for Роа аппиа and disease control in golf putting greens Proc. Southern Weed Sci. Soc. 39:113127,
Heiny, D. K., A.S. Mintz, and G.J. Weidemann. 1991. Redisposition of Aposhaenia amaranthi in Microsphaeropsis. Mycotaxon 44:137-154.

Johnson, B.J. 1975. Dates of herbicide application for weed control in bermudagrass. Weed Sci 23:110-115.

Johnson, B.J. 1983. Response to ethofumesate of annual bluegrass (Роа аппиа) and overseeded bermudagrass (Cynodon dactylon). Weed Sci. 31:385-390.

Johnson, B.J. 1984. Management of herbicides for weed control in bermudagrass turf. Georgia Agr. Res. Bul. 313.

Johnson, B.J. 1988a. Influence of herbicides on bermudagrass greens overseeded with perennial ryegrass. J. Amer. Soc. Hort. Sci. 113:662-666.

Johnson, B.J. 1988b. Fenarimol for control of annual bluegrass in dormant bermudagrass turf. Georgia Agr. Res. Rpt. 552.

Kalmowitz, K. E., T. J. Monaco, D.F. Ritchie, and P.S. Zomer, 1992. Xanthomonas control of annual bluegrass (Роа аппиа L.) is influenced by temperature and inoculum concentration. Proc. Southern Weed Sci. Soc. 45:135.

Mazur, A.R. 1976. Preemergence control of annual bluegrass in overseeded dormant bermudagrass putting green turf. Weed Sci. Soc. Amer. p. 1175-1176. (Abstr.)

Neal, J.N., T. Zhou, and N.D. Williams. 1992. Annual bluegrass control with Xanthomonas campestris pv. poannua. 1992 Progress Proc. New York State Pest Mgt. Conf. 55:6-14.

Phatak, S. C.. DR. Sammer, H.D. Wells, D.K. Bell, and N.C. Glaze. 1983. Biological control of yellow nutsedge with the indigenous rust fungus Puccinia canaliculata. Science 219:14461447.

Riddle, GE., L.L. Burpee, and G.J. Boland. 1991, Viruence of Sclerotinia sclerotinorum and $S$. minor on dandelion (Taxaxacum officinale). Weed Sci. 39: 109-1 18.

Roberts, D.L. and J.M. Vargas, Jr. 1984. Bacterial wilt: A potentially devastating threat. Golf Course Mgt. 84(4):33, 37,39,41.

Roberts, D. L., J.M. Vargas, Jr., R. Detweiler, K.K. Baker, and G.R. Hooper. 1981, Association of a bacterium with a disease of Toronto creeping bentgrass. Plant Dis. 65:1014-1016.

SAS Institute. 1982. SAS user's guide. SAS Institute, Cary, N.C.

Weidemann,G.J., D.O. TeBeest, and G.E. Templeton, 1992. Fungal plant pathogens used for biological weed control. Ark. Farming Res.41 (4):6-7. 